Article

\title{
A Two-Stage Continuous Fermentation System for Conversion of Syngas into Ethanol
}

\author{
Hanno Richter, Michael E. Martin and Largus T. Angenent * \\ Department of Biological and Environmental Engineering, Cornell University, Riley-Robb Hall, \\ Ithaca, NY 14853, USA; E-Mails: hr95@cornell.edu (H.R.); mem232@cornell.edu (M.E.M.) \\ * Author to whom correspondence should be addressed; E-Mail: 1a249@cornell.edu; \\ Tel.: +1-607-255-2480; Fax: +1-607-255-4449.
}

Received: 29 June 2013; in revised form: 24 July 2013 / Accepted: 27 July 2013 /

Published: 7 August 2013

\begin{abstract}
We have established a two-stage continuous fermentation process for production of ethanol from synthesis gas (syngas) with Clostridium ljungdahlii. The system consists of a 1-L continuously stirred tank reactor as a growth stage and a 4-L bubble column equipped with a cell recycle module as an ethanol production stage. Operating conditions in both stages were optimized for the respective purpose (growth in stage one and alcohol formation in stage two). The system was fed with an artificial syngas mixture, mimicking the composition of syngas derived from lignocellulosic biomass $\left(60 \% \mathrm{CO}, 35 \% \mathrm{H}_{2}\right.$, and $5 \%$ $\mathrm{CO}_{2}$ ). Gas recycling was used to increase the contact area and retention time of gas in the liquid phase, improving mass transfer and metabolic rates. In stage two, the biocatalyst was maintained at high cell densities of up to $10 \mathrm{~g} \mathrm{DW} / \mathrm{L}$. Ethanol was continuously produced at concentrations of up to $450 \mathrm{mM}(2.1 \%)$ and ethanol production rates of up to $0.37 \mathrm{~g} /(\mathrm{L} \cdot \mathrm{h})$. Foam control was essential to maintain reactor stability. A stoichiometric evaluation of the optimized process revealed that the recovery of carbon and hydrogen from the provided carbon monoxide and hydrogen in the produced ethanol was $28 \%$ and $74 \%$, respectively.
\end{abstract}

Keywords: syngas; ethanol; Clostridium ljungdahlii; mass transfer; continuous culture 


\section{Introduction}

Pyrolysis of organic materials, including lignocellulosic feedstocks, to obtain producer gas (synthesis gas or syngas) and subsequent fermentation of the syngas into ethanol and other short-chain hydrocarbon compounds is a strategy for production of bioalcohols that has been developing since the 1980s. Syngas derived from biomass is a mixture of carbon monoxide, hydrogen, and carbon dioxide, with other impurities, such as methane, hydrogen sulfide, nitrogen compounds, tars, and traces of other hydrocarbon and aromatic compounds. Microbes with promising capabilities to ferment carbon monoxide, hydrogen, and carbon dioxide into ethanol and other products have been isolated, and the biochemistry of these so-called acetogenic carboxydotrophic bacteria is well explained in the literature [1,2]. Several comprehensive reviews on syngas fermentation have recently been published [3-5].

Still, there are only a handful of scientific publications that focus on the technical and energetic feasibility of syngas fermentation. Some of the studies employ continuously stirred tank reactors (CSTRs) with one or two stages and cell recycling to increase mass transfer of substrate gases, density of biocatalyst and productivity [6-10]. Most reports focus on the concentration of products, and on the ratio of ethanol:acetic acid produced. Few reports actually provide information about specific rates of formation of the product(s) of interest, specifically ethanol. To our knowledge, the highest ethanol productivities of $1.6 \mathrm{~g} /(\mathrm{L} \cdot \mathrm{h})$ and $15 \mathrm{~g} /(\mathrm{L} \cdot \mathrm{h})$ have been reported in a patent for CSTR systems with a headspace pressure of 1 or 6 atmospheres, respectively, for Clostridium ljungdahlii strain C-01 [6].

The main product of syngas fermenting carboxydodrophic clostridia is usually acetic acid. Formation of acetic acid or ethanol from syngas has been reported for C. ljungdahlii, analogous to formation of butyric acid or butanol during acidogenesis or solventogenesis, by ABE fermenting clostridia [11]. In the following, we will use the terms "acidogenesis" and "solventogenesis" for formation of either acetic acid or ethanol, while we want to emphasize that the molecular mechanisms for production of carboxylic acids and conversion of carboxylic acids into alcohols are much different in $\mathrm{ABE}$ fermentation vs. syngas fermentation. The key mechanisms for ABE fermentation involve glycolysis, thiolase, and CoA-transferase, while this is the Wood-Ljungdahl pathway, and aldehydeoxidoreductase for syngas fermentation [1,11]. During syngas fermentation, acidogenesis occurs at high growth rates at favorable growth conditions (sufficient supply with nutrients, such as vitamins and minerals, optimal $\mathrm{pH}$ and temperature, and no end product inhibition), but somewhat limited supply with electron donor $\left(\mathrm{CO}\right.$ or $\left.\mathrm{H}_{2}\right)$. Solventogenesis, on the other hand, is favored during slow growth, in the presence of abundant electron donor [12], but otherwise unfavorable growth conditions, such as lower temperature, nutrient limitation [6] and lower $\mathrm{pH}[13,14]$. Another contributing factor is very likely end-product inhibition caused by high concentrations of (undissociated) acetic acid, analogous to butanol formation in solventogenic clostridia being triggered by similar factors and by undissociated butyric acid $[11,15]$.

For many fermentation processes, a continuous culture is seen as advantageous compared to a batch culture because in a continuous culture in general, the biocatalyst, once grown, remains viable for a long time (theoretically indefinitely), while batch cultures have to be re-grown after each fermentation run, before they become productive again. In case of syngas fermenting organisms, re-growing can take a long time, because of the relatively long doubling times, which would cause downtimes in the order of weeks for a commercial batch system. Then, the syngas at least, has to be supplied 
continuously, in contrast to sugar fermentations, where the substrate can be added to the liquid medium once, at the beginning of the run. In addition, a two-stage continuous culture with spatial separation of cell growth and ethanol production is likely to have numerous advantages over a single-stage continuous fermentation setup because: (1) the temperature and $\mathrm{pH}$ can be optimized separately in each stage; (2) the working volume of each stage can be adjusted to set different dilution and growth rates, to promote fast growth and acidogenesis in stage one, and growth stagnation, nutrient limitation, and solventogenesis in stage two (because of nutrient consumption in stage one and low dilution rates in stage two); (3) the acetic acid produced in stage one can be converted into ethanol in stage two during solventogenesis. The latter is even triggered by the additional acetic acid derived from stage one; (4) the accumulation of biocatalyst in stage two (because of lower dilution rate) is beneficial for high reactor productivity and can be further enhanced by cell recycling (filtering the effluent and keeping the cells in the reactor); and (5) the supply of nutrients into stage two can be individually altered (via a media bypass, see below) to adjust the balance between sufficient supply for cell viability and limitation of nutrients for maintaining the solventogenic state.

There are numerous studies suggesting that syngas fermentation rates can quickly become limited due to the supply of gaseous substrates because of the low solubility of carbon monoxide and hydrogen in water [3]. Continuously stirred tank reactors (CSTRs) and bubble columns, both with micro bubble generators, have been reported to be the most efficient reactor types for gas distribution. Bubble columns have the additional advantage that they require a lower volumetric energy input [16].

Here, we describe a continuous syngas fermentation system optimized for ethanol productivity, consisting of two stages operating at ambient pressure: (1) a growth stage (CSTR) operated at pH 5.5, allowing optimal growth of $C$. ljungdahlii while producing mainly acetic acid; and (2) a production stage (bubble column) operated at a lower $\mathrm{pH}$ to trigger solventogenesis and to achieve conversion of syngas and of acetic acid (from stage one) into ethanol. Stage two was equipped with a cell recycling module to accumulate biocatalyst, and a bypass to supply additional nutrient media from the reservoir, required by high cell densities. Both stages utilized gas recycling to improve residence time and mass transfer of the substrate gases in(to) the liquid media. Foam in stage two was controlled with an antifoam injection system, which was triggered by high foam levels.

\section{Results and Discussion}

\subsection{Cell Growth}

Stage one (growth stage): Once inoculated with $40 \mathrm{~mL}$ of preculture, stage one was first operated in batch mode to allow for a maximum initial increase of cell density. The $\mathrm{OD}_{600}$ increased from 0.030 to 0.814 within 2 days. Next, continuous operation was started with the pumping of fresh medium at a flow rate of $39 \mathrm{~mL} / \mathrm{h}$ (dilution rate $D=0.039 \mathrm{~h}^{-1}$ ). The cell density in stage one increased slowly until reaching an $\mathrm{OD}_{600}$ of $\sim 2.0$ after 4 more days, when equilibrium (growth rate $=$ dilution rate) was reached. This timepoint is plotted as $0 \mathrm{~h}$ in Figure 1. Two incidents had severe negative impact on stage 1, which recovered after the issues were fixed: (1) a leak in the gas recycle loop at $888 \mathrm{~h}$, causing oxygen to intrude; and (2) when $4 \times$ concentrated medium was supplied from hour 1562-1632. For estimation of the amount of acetic acid produced by a certain amount of cells, it is helpful to note that the concentration of acetic acid in stage one was always $\sim 100 \mathrm{mM}$ per $\mathrm{OD}_{600}$. Knowing that the 
coefficient for milligram dry weight per Liter per $\mathrm{OD}_{600}\left[\mathrm{mg} \mathrm{DW} /\left(\mathrm{L} \cdot \mathrm{OD}_{600}\right)\right]$ is 242 for C. ljungdahlii ERI-2 [17], one can estimate that $1 \mathrm{~g}$ DW of cell mass produced about 0.4 mol, or $24 \mathrm{~g}$ acetic acid. The ethanol concentration was generally a factor of 5-20 below the concentration of acetic acid throughout the entire run, illustrating that stage one was primarily acidogenic.

Figure 1. Stage one during continuous operation for $2014 \mathrm{~h}$ (83 days). Shown are the data for: (A) growth $\left(\mathrm{OD}_{600}\right)$; (B) $\mathrm{pH}$ value; $(\mathbf{C})$ concentration of the fermentation products ethanol and acetate in $\mathrm{mM}$; and (D) the average total daily feed rate of media (total media flow, $\mathrm{mL} / \mathrm{h}$ ). Arrows with comments indicate changes made to the system, explained in more detail in Table 1 and in the text.

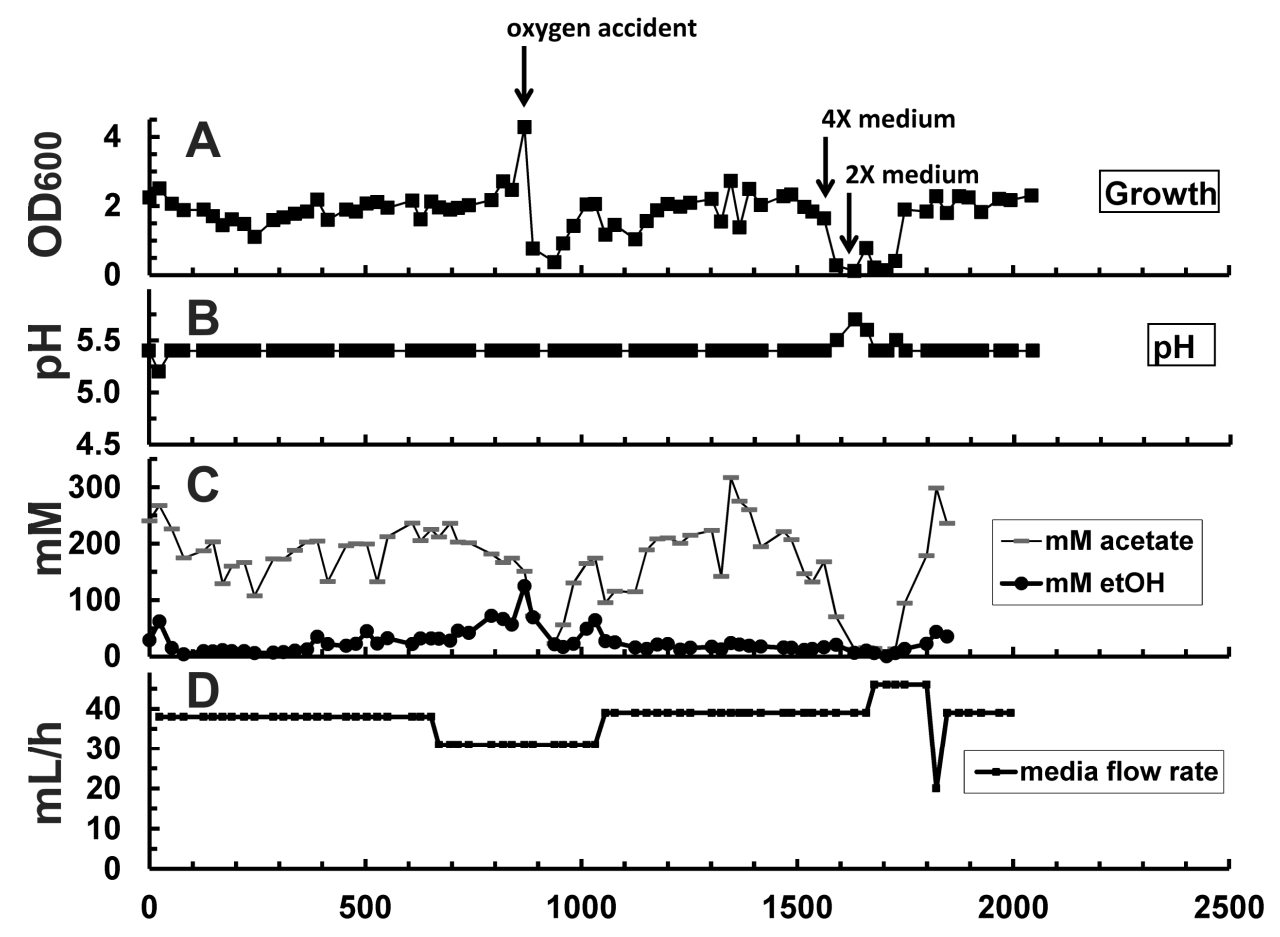

Stage two (production stage): Once growth equilibrium had been reached in stage one, its effluent was directed into stage two for inoculation and constant supply with grown cells and acetic acid. The $\mathrm{pH}$ in stage two was always maintained within a range of 4.4 to 4.8 (Figure 2B).

Media dilution rate in stage two was initially $0.01 \mathrm{~h}^{-1}$ at a media flow rate of $39 \mathrm{~mL} / \mathrm{h}$. In Table 1 , the operational changes made to stage one and stage two (during the continuous run) are summarized, as well as their effects on performance parameters. Overall, increasing the media flow and dilution rates resulted in lower $\mathrm{OD}_{600}$ and product concentrations in stage one because of a higher washout rate (not shown), but in a higher performance of stage two. For example, the maximum cell density $\left(\mathrm{OD}_{600}\right)$ increased from 9.9 to 17.8 , when the dilution rate in stage two was increased from 0.010 to 0.016 (Figure 2A, and Table 1, time point $650 \mathrm{~h}$ ). 
Figure 2. Performance of stage two during continuous operation for $2014 \mathrm{~h}$ (83 days). Shown are the data for: (A) growth $\left(\mathrm{OD}_{600}\right)$; (B) $\mathrm{pH}$ value; (C) concentration of the fermentation products ethanol and acetate in $\mathrm{mM}$; (D) the average daily ethanol production rate $(\mathrm{mmol} / \mathrm{min})$; (E) the average daily rates of consumption $(\mathrm{mmol} / \mathrm{min})$ for carbon monoxide and hydrogen and for production of carbon dioxide; $(\mathbf{F})$ the average daily molar ratios of carbon monoxide and hydrogen consumed $v s$. ethanol produced; and $(\mathbf{G})$ the average total daily feed rate of media (total media flow, $\mathrm{mL} / \mathrm{h}$ ). Arrows with comments indicate changes made to the system, which is explained in more detail in Table 1 and in the text. $1517 \mathrm{~h}$ is the timepoint at which stable performance at optimized conditions was achieved, and where performance data were taken for Table 2.

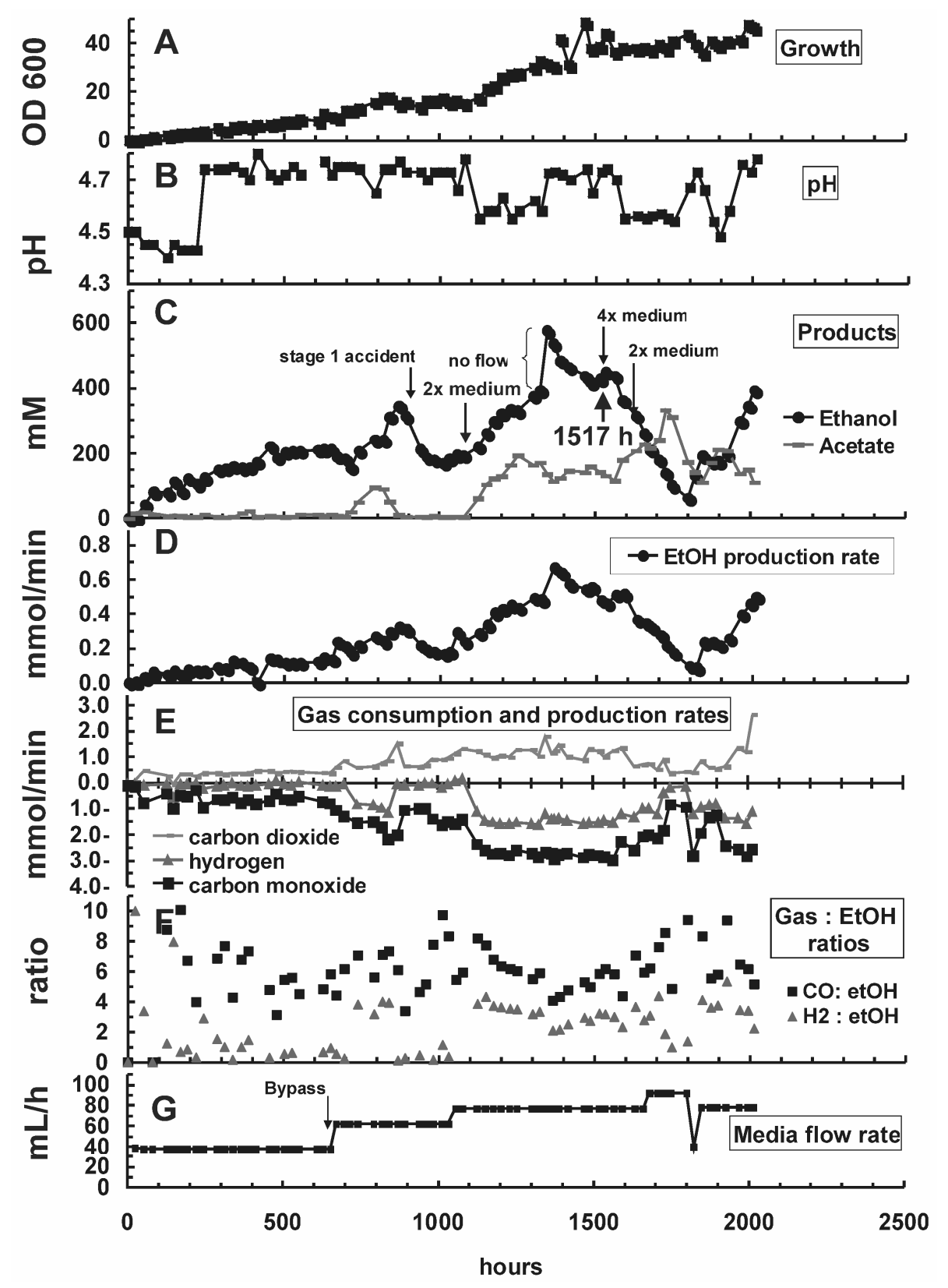


Table 1. Summary of changes in reactor operating conditions and their effect on reactor performance.

\begin{tabular}{|c|c|c|c|}
\hline \multirow[t]{2}{*}{ Hour } & $\begin{array}{l}\text { Change in reactor condition } \\
\text { (Figure 2B,G) }\end{array}$ & \multicolumn{2}{|c|}{$\begin{array}{l}\text { Effect on reactor performance } \\
\text { (Figure 2A, C-E) }\end{array}$} \\
\hline & Stage one & Stage one & Stage two \\
\hline $0-650$ & $\begin{array}{l}D=0.039 \mathrm{~h}^{-1} \\
\mathrm{pH}=5.5\end{array}$ & $\begin{array}{l}\text { Growth at equilibrium, } \\
\mathrm{OD}_{600} \text { at } \sim 2.0\end{array}$ & $\begin{array}{l}\text { Inoculation; } \\
\mathrm{OD}_{600} \text { increased at an initial rate of } 0.37 / \text { day to } \sim 9.9\end{array}$ \\
\hline $650-888$ & $\begin{array}{l}\text { Activated media bypass channel (Figure } 1 \text { ), } \\
\text { increased overall media flow rate by } 50 \% \text { to } 62 \mathrm{~mL} / \mathrm{h} \text {; } \\
\text { increased dilution rate in stage } 2 \text { relatively to stage } 1 \\
D=0.031 \mathrm{~h}^{-1} \quad D=0.016 \mathrm{~h}^{-1}\end{array}$ & $\mathrm{OD}_{600}$ increased to $\sim 2.4$ & $\begin{array}{l}\mathrm{OD}_{600} \text { increased to } 17.8 \text {; } \\
\text { higher reactor performance (Figure } 2 \mathrm{C}-\mathrm{E} \text { ) }\end{array}$ \\
\hline 888 & $\begin{array}{l}\text { ACCIDENT: ambient } \\
\text { air drawn into stage } 1\end{array}$ & $\begin{array}{l}\mathrm{OD}_{600} \text { declined to } 0.37 \text {, recovery } \\
\text { completed at } 1013 \mathrm{~h}\end{array}$ & $\begin{array}{l}\mathrm{OD}_{600} \text { was not affected, but metabolic rates declined } \\
\text { (Figure } 2 \mathrm{C}-\mathrm{E} \text { ) }\end{array}$ \\
\hline 1056 & $D=0.039 \mathrm{~h}^{-1} \quad D=0.020 \mathrm{~h}^{-1}$ & $\mathrm{OD}_{600}$ decreased to $\sim 2.0$ & $\mathrm{OD}_{600}$ increased to $\sim 30.0$ \\
\hline 1347 & $\begin{array}{l}\text { ACCIDENT: Media pump stopped for } \\
\text { several hours }\end{array}$ & & $\begin{array}{l}\text { Rapid increase of ethanol concentration from } \\
393 \text { to } 576 \mathrm{mM} \text {; stabilized at } 400-450 \mathrm{mM} \text { ethanol } \\
\text { within } 100 \mathrm{~h} \text { after repairing the pump }\end{array}$ \\
\hline 1366 & $\begin{array}{l}\text { Raised gas recycle rate from } \\
180 \text { to } 430 \mathrm{~mL} / \mathrm{min} \text { to } \\
\text { increase syngas retention time } \\
\text { and mass transfer }\end{array}$ & & $\begin{array}{l}\text { Stage 2: sudden rise of } \mathrm{OD}_{600} \text { to } 41.7 \text { (Figure } 2 \mathrm{~A} \text { ) due } \\
\text { to stir up of settled cells. } \mathrm{OD}_{600} \text { stayed at higher level } \\
\text { until end of experiment.Syngas consumption did not } \\
\text { improve significantly (Figure 2E) }\end{array}$ \\
\hline $1535-1632$ & $\begin{array}{l}2 \times \text { medium was exchanged with } 4 \times \text { medium in the } \\
\text { reservoir for } 97 \mathrm{~h} \text { to improve supply with nutrients }\end{array}$ & $\begin{array}{l}\mathrm{OD}_{600} \text { declined from } 2.0 \text { to } 0.1 . \\
\text { Recovery completed at } 1749 \mathrm{~h} .\end{array}$ & $\begin{array}{l}\text { Salt shock did not affect } \mathrm{OD}_{600}, \text { but metabolic rates } \\
\text { declined. Recovery started at } 1800 \mathrm{~h}\end{array}$ \\
\hline 1679 & $D=0.023 \mathrm{~h}^{-1}$ & New $\mathrm{OD}_{600}$ level settled at $\sim 1.8$ & New $\mathrm{OD}_{600}$ level settled at $\sim 43.4$ \\
\hline 1800 & $D=0.039 \mathrm{~h}^{-1}$ & $\mathrm{OD}_{600}$ back at $\sim 2.0$ & Recovery from salt shock started \\
\hline 2014 & End of experiment & & Final $\mathrm{OD}_{600}$ of 46.2 ; ethanol concentration of $394 \mathrm{mM}$ \\
\hline
\end{tabular}


Table 2. Performance parameters of continuous operation of the 2-stage system at time point $1517 \mathrm{~h}$ at which stable operating conditions had been achieved. These parameters were used to calculate the fermentation balance explained in the text. The gas inlets for stage 1 and 2 contained the same gas, and are therefore summarized in one column. Abbreviations: $(\mathrm{G})$ and (L) indicate gas or liquid state at ambient conditions; g DW/L: gram dry weight per liter.

\begin{tabular}{|c|c|c|c|}
\hline \multirow{2}{*}{ Compound } & \multicolumn{3}{|c|}{ Concentrations } \\
\hline & Outlet stage 1 & Outlet stage 2 & Inlet stages $1 \& 2$ \\
\hline CO $(\mathrm{G}),(\mathrm{vol} \%)$ & 53 & 19 & 60 \\
\hline $\mathrm{H}_{2}(\mathrm{G}),(\mathrm{vol} \%)$ & 34 & 14 & 35 \\
\hline $\mathrm{CO}_{2}(\mathrm{G}),(\mathrm{vol} \%)$ & 13 & 63 & 5 \\
\hline Ethanol (L), (mM) & 11.5 & 428.4 & NA \\
\hline Acetic acid $(\mathrm{L}),(\mathrm{mM})$ & 146.5 & 142.5 & NA \\
\hline Bacteria (g DW/L) & 0.476 & 9.34 & NA \\
\hline \multirow{2}{*}{ Compounds } & \multicolumn{3}{|c|}{ Rates $[\mathrm{mmol} /(\mathbf{L} \cdot \min )]$} \\
\hline & Stage 1 & Stage 2 & Total \\
\hline $\mathrm{CO}$ in & 0.607 & 0.808 & 0.768 \\
\hline $\mathrm{CO}$ out & 0.330 & 0.110 & 0.154 \\
\hline CO consumption & 0.277 & 0.698 & 0.614 \\
\hline $\mathrm{H}_{2}$ in & 0.354 & 0.471 & 0.448 \\
\hline $\mathrm{H}_{2}$ out & 0.182 & 0.085 & 0.105 \\
\hline $\mathrm{H}_{2}$ consumption & 0.172 & 0.386 & 0.343 \\
\hline $\mathrm{CO}_{2}$ in & 0.051 & 0.067 & 0.064 \\
\hline $\mathrm{CO}_{2}$ out & 0.085 & 0.371 & 0.314 \\
\hline $\mathrm{CO}_{2}$ production & 0.034 & 0.303 & 0.250 \\
\hline Ethanol production & 0.007 & 0.136 & 0.110 \\
\hline Acetic acid production & 0.094 & 0.025 & 0.039 \\
\hline \multirow{2}{*}{ Compounds } & \multicolumn{3}{|c|}{ Efficiencies (\%) } \\
\hline & Stage 1 & Stage 2 & Total \\
\hline CO consumption & 46 & 86 & 80 \\
\hline $\mathrm{H}_{2}$ consumption & 49 & 82 & 77 \\
\hline
\end{tabular}

When the dilution rate was further increased, and the nutrient concentration in the media was raised to $2 \times$ (Figure 2, and Table 1, time point $1056 \mathrm{~h}$ ), the $\mathrm{OD}_{600}$ increased to around 30 . Higher dilution rates, and rates of nutrient supply sustained a higher $\mathrm{OD}_{600}$ (washout of grown cells was prevented in stage two). The $\mathrm{OD}_{600}$ did not rise infinitely in stage two (in spite of the cell filtration module) because at the maximum $\mathrm{OD}_{600}$, the rate of cell lysis had reached the rate of new cells entering from stage one. An attempt to increase the nutrient concentration to $4 \times$ (Figure 2, Table 1, time point $1535 \mathrm{~h}$ ), resulted in a rapid loss of reactor viability, which could only be restored when the nutrient concentration was reverted to $2 \times$. It is likely that the increased osmolarity in the $4 \times$ concentrated medium, conveyed mainly by the minerals chloride (407 mM), ammonium (224 mM), and sodium (164 mM), caused the bacteria to undergo salt stress. In addition, ammonium is known to be toxic to bacteria at high concentrations. We believe we can exclude that trace metals acted inhibitory. Although several trace metals are known to be toxic or inhibitory to cellular processes at higher concentrations, a recent study 
with Clostridium ragsdalei showed that a 10 -fold increase of trace metal concentration did not result in decreased metabolic acitivities [18]. Another interesting detail is that the cell density did not decrease while the metabolic activity almost completely declined due to the salt shock. This could have occurred because of spore formation instead of cell death and lysis as a response to salt stress, but this was not further investigated.

Increasing the gas recycle rate independent from the media flow rate (Table 1, time point $1366 \mathrm{~h}$ ) did not result in an increase in cell density beyond the increase caused by stirring up settled cells, which had accumulated throughout the fermentation run against the conical side walls at the bottom of the reactor. This indicates that cell growth (and productivity) at this high cell density were rather limited by the media dilution rate (nutrient supply and product removal), than by mass transfer of substrate gas into the liquid phase. This was surprising, given that mass transfer is considered a major limiting factor in the literature, and the cell densities reached in our system surpassed ones reported in literature by far. It is, therefore, likely that a large proportion of cells in our reactor was inactive, due to nutrient limitation. However, in our experimental setup, it was not feasible to test if higher dilution rates would further improve reactor performance.

\subsection{Substrate Consumption and Product Formation}

Our data demonstrate that acetic acid from stage one was converted into ethanol during solventogenesis in stage two. This is particularly evident during hour 0-600, when the acetic acid concentration in stage one oscillated around $200 \mathrm{mM}$, while in stage two the acetic acid concentration remained around 5-20 mM, while the ethanol concentration increased continuously up to around $200 \mathrm{mM}$. Under continuous optimal conditions, constant ethanol concentrations in stage two were between 400 and $450 \mathrm{mM}(20.7 \mathrm{~g} / \mathrm{L})$. The time point $1517 \mathrm{~h}$ of the operating period is used as a reference at which the ethanol concentration was $428 \mathrm{mM}$, while the ethanol production rate of the entire system was $0.549 \mathrm{mmol} / \mathrm{min}$ (Table 2). This corresponds to an overall ethanol production rate of $0.303 \mathrm{~g} /(\mathrm{L} \cdot \mathrm{h}$ ). The ethanol production in stage two alone was $0.374 \mathrm{~g} /(\mathrm{L} \cdot \mathrm{h})$. This is below the rate of $1.6 \mathrm{~g} /(\mathrm{L} \cdot \mathrm{h})$ achieved by Gaddy et al. [6], although the cell density in our reactor was higher (10 vs. $2 \mathrm{~g} \mathrm{DW} / \mathrm{L})$, and our fermentation was not mass transfer limited. As outlined above, it is likely that a large proportion of cells in our stage two reactor was inactive due to nutrient limitation. Higher rates of nutrient supply (increasing the rate of supply rather than the concentration) can be achieved via increased media flow (dilution) rates in stage 2, and this will be a future strategy to improve rates of product formation.

The molar ratio of ethanol:acetic acid in stage two at our reference point was 2.8. The relative proportion of acetic acid increased when dilution rate and cell density were increasing (Figure 2A,C,G). The ratio of acetic acid was much lower during times when the system had been operated undisturbed at a steady dilution rate, and when the $\mathrm{OD}_{600}$ was at maximum (e.g., at time points $628 \mathrm{~h}$ and $869 \mathrm{~h}$ ) with molar ratios of ethanol:acetic acid of 28 and 29, respectively. The molar ratios of $\mathrm{CO}$ and $\mathrm{H}_{2}$ consumed vs. ethanol produced (Figure $2 \mathrm{~F}$ ) were not constant throughout the operation. During times when cell density increased, the ratios went up to levels significantly higher than theoretical values, because growth and production of acetic acid required additional carbon, ATP, and reducing equivalents. During times of optimum ethanol production and no growth, the ratios were closer to ideal 
stoichiometries reported in the literature [3]. The overall fermentation stoichiometry calculated for our system during optimum performance at $1517 \mathrm{~h}$ is described by the following equation derived using data from Table 1:

$$
5.58 \mathrm{CO}+3.12 \mathrm{H}_{2} \rightarrow 1.00 \text { ethanol }+0.35 \text { acetate }+2.27 \mathrm{CO}_{2}
$$

From this equation, carbon recovery and redox balance can be calculated as $89 \%$ and 0.93 , respectively. A perfectly balanced fermentation would have resulted in values of $100 \%$ carbon recovery and a redox balance of 1.00 [19]. It was verified by HPLC that fermentation byproducts common for homoacetogenic bacteria, such as formic, lactic, or $n$-butyric acid, $n$-butanol [2], and isopropanol [20], were not produced. We did observe a peak in the HPLC with a retention time corresponding to 2,3-butanediol, which is a known fermentation product of C. ljungdahlii [21]. However, its concentration could not be exactly quantified, but always remained below $1 \mathrm{mM}$, which would contribute a less than $1 \%$ change to the fermentation balance. Another potential loss of carbon could have occurred by stripping of ethanol via the gas flow, but this had not been tested for. We explain the slightly unbalanced fermentation by formation of 2,3-butanediol, ethanol stripping, and fluctuations in performance during the continuous operation and by the fact that carbon flux into biomass was not considered (but estimated to be $\sim 0.5 \%$ of the $\mathrm{CO}$ consumed). Considering the loss of syngas that was not consumed (Table 1), $28 \%$ of the carbon contained in carbon monoxide provided, and $74 \%$ of the hydrogen provided were recovered in ethanol. With the syngas composition of $\mathrm{CO}: \mathrm{H}_{2}: \mathrm{CO}_{2}$ of $60: 35: 5$, a theoretical carbon recovery of 53\% from carbon monoxide, and a hydrogen recovery of $100 \%$ in ethanol is expected, according to the theoretical stoichiometric fermentation balance:

$$
3.79 \mathrm{CO}+2.21 \mathrm{H}_{2}+0.79 \mathrm{H}_{2} \mathrm{O} \rightarrow 1 \mathrm{EtOH}+1.79 \mathrm{CO}_{2}
$$

Therefore, the current setup achieved $53 \%$ and $74 \%$ of the theoretical possible recovery of carbon from carbon monoxide and hydrogen from hydrogen, respectively, in the product ethanol, suggesting that some improvement of performance is still possible by optimizing parameters such as rates of dilution, nutrient supply, and gas supply, and the ratio of ethanol: acetic acid.

The experiment was not replicated. However, we anticipate that we would obtain similar results for product concentrations and rates of formation if we repeated the experiment with the same operational parameters as those applied around timepoint $1517 \mathrm{~h}$. Indeed, comparable reactor performance was achieved after the culture had recovered from the salt shock at the end of the operational run (Figure 1D).

\section{Experimental Section}

All chemicals were obtained from Sigma-Aldrich (St. Louis, MO, USA) except for syngas for which a blend of $60 \%$ (vol/vol) $\mathrm{CO}, 35 \% \mathrm{H}_{2}$, and $5 \% \mathrm{CO}_{2}$ was used (Airgas East, Ithaca, NY, USA).

\subsection{Biocatalyst and Growth Conditions}

C. ljungdahlii ERI-2 (ATCC 55380) was used as a biocatalyst, since it had proven to be a good ethanol producer [17]. Bacteria were always grown anaerobically at $35{ }^{\circ} \mathrm{C}$ in medium designed for efficient syngas fermentation [22], which is referred to here as $1 \times$ medium. Precultures were grown in $160-\mathrm{mL}$ serum bottles containing $10 \mathrm{~mL}$ of $1 \times$ medium adjusted to $\mathrm{pH} 5.5$, and syngas in the 
headspace at a pressure of 1.93 bar. Precultures were maintained by weekly transfer of $2 \%$ (vol/vol). The concentration of MES (2-(N-morpholino)ethanesulfonic acid) buffer was $5 \mathrm{~g} / \mathrm{L}$ in the precultures, and in the initial startup medium in the 1-L CSTR fermentor, where yeast extract was added at $0.05 \mathrm{~g} / \mathrm{L}$ to promote initial growth. Yeast extract and MES were omitted from medium in stage two, and from the continuous feed medium in which the $\mathrm{pH}$ was controlled via addition of $2 \mathrm{M} \mathrm{KOH}$ or $\mathrm{HCl}$. Prior to inoculation of stage one, stage one and two were filled with $1 \mathrm{~L}$ and $4 \mathrm{~L}$ of $1 \times$ concentrated growth medium, respectively. The $\mathrm{pH}$ setpoints in stage one were 5.5 (low) and 5.7 (high), with the actual medium $\mathrm{pH}$ always being at the low end of the range due to acidogenesis. In stage two, the $\mathrm{pH}$ setpoints were 4.4 (low) to prevent acid crash in case the culture turned acidogenic, and 4.8 (high) to prevent the culture from turning acidogenic in the first place. In the sourcemedium for continuous operation, the concentration of all minerals, trace elements, and vitamins was doubled ( $2 \times$ medium) or quadrupled ( $4 \times$ medium), after a maximum $\mathrm{OD}_{600}$ had been reached in stage two with $1 \times$ medium. Antifoam 204 (Sigma-Aldrich, St. Louis, MO, USA) was added to the medium reservoir at $10 \mu \mathrm{L} / \mathrm{L}$, which prevented foaming in stage one. In stage two, because of high cell densities, a foam controller (Cole Parmer, Vernon Hills, IL, USA) was installed to deliver antifoam 204 solution $(100 \times$ diluted) on demand. The antifoam amounts and concentrations had been carefully determined in previous experiments to provide efficient foam control without killing the cells by adding too much of the agent, which seems to be toxic to $C$. ljungdahlii. In stage two, a total of $462.5 \mathrm{~mL}$ of $100 \times$ diluted Antifoam 204 was consumed during the entire run at an average rate of $0.236 \mathrm{~mL} / \mathrm{h}$.

\subsection{Reactor Setup}

The two-stage continuous system was set up according to Figure 3. The stage one fermentor was a 2-L Braun Biostat M CSTR (Braun, Allentown, PA, USA) with 1 L working volume. The agitation speed was $200 \mathrm{rpm}$. Stage two was a custom-made 6-L bubble column with $4 \mathrm{~L}$ working volume. Both systems were equipped with temperature (water jacket), and $\mathrm{pH}$ control. Stage two was equipped with a foam control system (Cole Parmer, Vernon Hills, IL, USA) that injected 100× diluted antifoam 204 solution upon detection of high foam levels.

Peristaltic media pumps (Cole Parmer) \#1-4 and gas-recycle pump \#7 were operated at variable flow-rate, while the cell recycle pump \#5 and gas recycle pump \#6 were set to $180 \mathrm{~mL} / \mathrm{min}$. Microbubble spargers (MoreFlavor, Concord, CA, USA) were made of stainless steel with a pore size of $0.5 \mu \mathrm{m}$. Foam traps in the gas recycle lines prevented clogging of microspargers. The rates of syngas supply into both stages were maintained at levels that exceeded the consumption by at least $10 \%$ to avoid limitation of gaseous substrate, which has been reported to be detrimental for ethanol production [6]. Flexible tubing (Cole Parmer) was norprene for liquid lines, and viton for the gas lines, respectively, since viton has a low gas permeability. The cell recycle module was a Cellflo polyethersulfone hollow fiber module with $500-\mathrm{cm}^{2}$ membrane surface area and $0.2-\mu \mathrm{m}$ pore size (C22E-011-01N, Spectrum Laboratories, Inc., Rancho Dominguez, CA, USA). 
Figure 3. Setup of two-stage continuous fermentation with cell and gas recycle. Solid lines: flow of liquid media; dotted lines: flow of substrate and exhaust gases. Abbreviations: 1-7 pumps; Ag, agitation; BP, bypass; E, effluent reservoir; Ex, exhaust; FT, foam trap; G1, G2, gas recycle loops; HF, hollow fiber module for cell recycle; $\mathrm{M}$, media reservoir; Per, permeate; Ret, retentate.

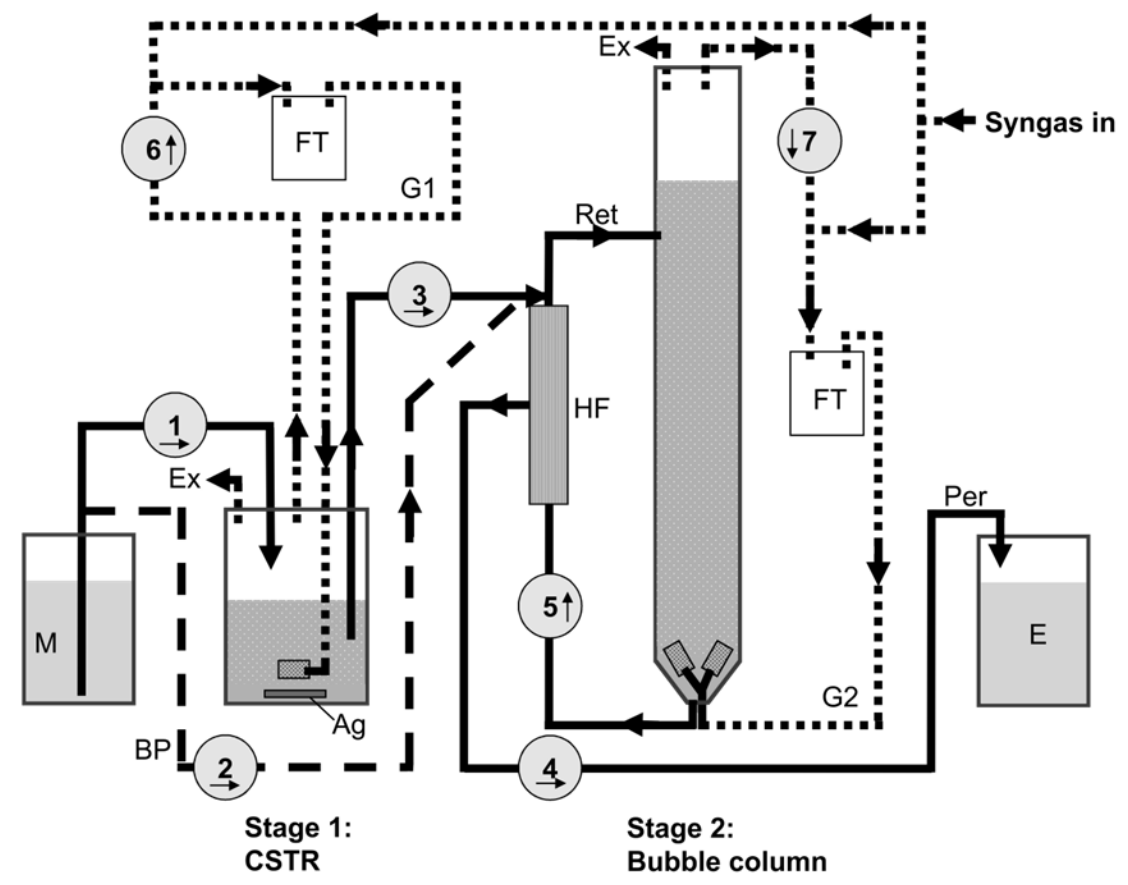

\subsection{Analytical Procedures}

Liquid media aliquots of both stages were analyzed daily for ethanol, acetic acid, and other possible metabolites by HPLC (Waters, Milford, MA, USA) with an Aminex HPX87H column (Bio-Rad, Hercules, CA, USA) kept at $65^{\circ} \mathrm{C}$ and an RI-detector. HPLC buffer was $5 \mathrm{mM}$ sulfuric acid in water, and the flow rate was $0.6 \mathrm{~mL} / \mathrm{min}$. Volumetric gas flow rates and gas pressures in the fermentation system were measured with in-line volumetric flow meters (custom-made), bubble flow meters, and digital pressure gauges (ColeParmer) at the gas inlets and outlets of both stages. Concentrations of carbon monoxide, hydrogen, and carbon dioxide, and cell dry weight were determined as previously described [17]. Both fermentation stages were checked for possible contaminants via daily controls of liquid samples using a phase-contrast microscope. The flow rate of media was adjusted and monitored by measuring the volume of effluent. The amount of $2 \mathrm{M}$ aqueous solutions of $\mathrm{KOH}$ and $\mathrm{HCl}$ spent for $\mathrm{pH}$ adjustment was measured daily by weighing the reservoir bottles. This was useful to immediately evaluate if the stage-two reactor was solventogenic: pumping of $\mathrm{HCl}$ always correlated with high rates of ethanol formation. This can be explained by the consumption of acetic acid by the bacteria, and the resulting increase in the $\mathrm{pH}$.

\section{Conclusions and Outlook}

The ethanol productivity of $0.374 \mathrm{~g} /(\mathrm{L} \cdot \mathrm{h}$ ) (in stage two) is promising. Compared to typical average ethanol production rates during hexose fermentation by yeast in commercial bioethanol plants 
1.25-3.75 $\mathrm{g} /(\mathrm{L} \cdot \mathrm{h})$ [23], syngas fermentation has potential to reach or even succeed these rates, and we are optimistic to further improve the performance, especially since current efforts in commercializing the process by companies such as Lanzatech (Roselle, IL, USA), Coskata (Warrenville, IL, USA), and IneosBio (Lisle, IL, USA) suggest that this is possible. However, challenges for economic continuous syngas fermentation remain:

- The relatively low ethanol concentration of $2 \%$ in the effluent requires advanced strategies for distillation to keep the energy balance of the entire process positive. A promising method has been described recently [24];

- When feeding the fermentation with "real world" producer gas derived from pyrolysis of biomass, toxic contaminants that inhibit syngas fermentation [7,25] have to be removed by a gas cleaning process;

- The relatively high costs for media ingredients required to support growth of the biocatalyst [26,27] suggest that the operational costs of syngas fermentation will remain in an uneconomical range, unless cheaper sources of growth medium are found for this process.

\section{Acknowledgements}

Funding was provided by Yossie Hollander and the Foundation des Fondateurs. In addition, this work was possible thanks to the U.S. Department of Transportation, which provided funding to support it under contract to the Northeast Sun Grant Initiative at Cornell University \# US DOT Assistance \# DTOS59-07-G-00052.

\section{Conflict of Interest}

The authors declare no conflict of interest.

\section{References}

1. Köpke, M.; Held, C.; Hujer, S.; Liesegang, H.; Wiezer, A.; Wollherr, A.; Ehrenreich, A.; Liebl, W.; Gottschalk, G.; Dürre, P. Clostridium ljungdahlii represents a microbial production platform based on syngas. Proc. Natl. Acad. Sci. USA 2010, 107, 13087-13092.

2. Henstra, A.M.; Sipma, J.; Rinzema, A.; Stams, A.J. Microbiology of synthesis gas fermentation for biofuel production. Curr. Opin. Biotechnol. 2007, 18, 200-206.

3. Munasinghe, P.C.; Khanal, S.K. Biomass-derived syngas fermentation into biofuels: Opportunities and challenges. Bioresour. Technol. 2010, 101, 5013-5022.

4. Daniell, J.; Köpke, M.; Simpson, S.D. Commercial biomass syngas fermentation. Energies 2012, 5, 5372-5417.

5. Abubackar, H.N.; Veiga, M.C.; Kennes, C. Biological conversion of carbon monoxide: Rich syngas or waste gases to bioethanol. Biofuels Bioprod. Biorefin. 2011, 5, 93-114.

6. Gaddy, J.L.; Arora, D.K.; Ko, C.-W.; Phillips, J.R.; Basu, R.; Wikstrom, K.V.; Clausen, E.C. Methods for Increasing the Production of Ethanol from Microbial Fermentation. U.S. Patent 7,285,402 B2, 23 October 2003. 
7. Kundiyana, D.K.; Huhnke, R.L.; Wilkins, M.R. Syngas fermentation in a 100-L pilot scale fermentor: Design and process considerations. J. Biosci. Bioeng. 2010, 109, 492-198.

8. Klasson, K.T.; Ackerson, M.D.; Clausen, E.C.; Gaddy, J.L. Biological conversion of coal and coal-derived synthesis gas. Fuel 1993, 72, 1673-1678.

9. Klasson, K.; Elmore, B.; Vega, J.; Ackerson, M.; Clausen, E.; Gaddy, J. Biological production of liquid and gaseous fuels from synthesis gas. Appl. Biochem. Biotechnol. 1990, 24-25, 857-873.

10. Kundiyana, D.K.; Huhnke, R.L.; Wilkins, M.R. Effect of nutrient limitation and two-stage continuous fermentor design on productivities during "Clostridium ragsdalei" syngas fermentation. Bioresour. Technol. 2011, 102, 6058-6064.

11. Jones, D.T.; Woods, D.R. Acetone-butanol fermentation revisited. Microbiol. Rev. 1986, 50, 484-524.

12. Younesi, H.; Najafpour, G.; Mohamed, A.R. Ethanol and acetate production from synthesis gas via fermentation processes using anaerobic bacterium, Clostridium ljungdahlii. Biochem. Eng. J. 2005, 27, 110-119.

13. Worden, R.M.; Grethlein, A.J.; Jain, M.K.; Datta, R. Production of butanol and ethanol from synthesis gas via fermentation. Fuel 1991, 70, 615-619.

14. Abubackar, H.N.; Veiga, M.C.; Kennes, C. Biological conversion of carbon monoxide to ethanol: Effect of $\mathrm{pH}$, gas pressure, reducing agent and yeast extract. Bioresour. Technol. 2012, 114, 518-522.

15. Richter, H.; Qureshi, N.; Heger, S.; Dien, B.; Cotta, M.A.; Angenent, L.T. Prolonged conversion of $n$-butyrate to $n$-butanol with Clostridium saccharoperbutylacetonicum in a two-stage continuous culture with in-situ product removal. Biotechnol. Bioeng. 2012, 109, 913-921.

16. Bredwell, M.D.; Worden, R.M. Mass-transfer properties of microbubbles. 1. Experimental studies. Biotechnol. Prog. 1998, 14, 31-38.

17. Perez, J.M.; Richter, H.; Loftus, S.E.; Angenent, L.T. Biocatalytic reduction of short-chain carboxylic acids into their corresponding alcohols with syngas fermentation. Biotechnol. Bioeng. 2013, 110, 1066-1077.

18. Saxena, J.; Tanner, R.S. Effect of trace metals on ethanol production from synthesis gas by the ethanologenic acetogen, Clostridium ragsdalei. J. Ind. Microbiol. Biotechnol. 2011, 38, 513-521.

19. Buckel, W. Anaerobic Energy Metabolism. In Biology of the Prokaryotes; Lengeler, J.W., Drews, G., Schlegel, H.G., Eds.; Thieme: Stuttgart, Germany, 1999; pp. 278-326.

20. Ramachandriya, K.D.; Wilkins, M.R.; Delorme, M.J.M.; Zhu, X.; Kundiyana, D.K.; Atiyeh, H.K.; Huhnke, R.L. Reduction of acetone to isopropanol using producer gas fermenting microbes. Biotechnol. Bioeng. 2011, 108, 2330-2338.

21. Köpke, M.; Mihalcea, C.; Liew, F.; Tizard, J.H.; Ali, M.S.; Conolly, J.J.; Al-Sinawi, B.; Simpson, S.D. 2,3-butanediol production by acetogenic bacteria, an alternative route to chemical synthesis, using industrial waste gas. Appl. Environ. Microbiol. 2011, 77, 5467-5475.

22. Datar, R.P.; Shenkman, R.M.; Cateni, B.G.; Huhnke, R.L.; Lewis, R.S. Fermentation of biomass-generated producer gas to ethanol. Biotechnol. Bioeng. 2004, 86, 587-594.

23. Website of Bio-Process Innovation, Inc.. Available online: www.bio-process.com/processtechnologies/fermentation (accessed on 30 July 2013). 
24. Vane, L.M.; Alvarez, F.R.; Huang, Y.; Baker, R.W. Experimental validation of hybrid distillation-vapor permeation process for energy efficient ethanol-water separation. J. Chem. Technol. Biotechnol. 2010, 85, 502-511.

25. Xu, D.; Tree, D.R.; Lewis, R.S. The effects of syngas impurities on syngas fermentation to liquid fuels. Biomass Bioenergy 2011, 35, 2690-2696.

26. Phillips, J.R.; Remondet, N.M.; Atiyeh, H.K.; Wilkins, M.R.; Huhnke, R.L. Designing Syngas Fermentation Medium for Fuels and Bulk Chemicals Production. In Proceedings of 2011 ASABE Annual International Meeting, Louisville, KY, USA, 7-10 August 2011; paper \# 1111052; pp. 1-12.

27. Saxena, J.; Tanner, R. Optimization of a corn steep medium for production of ethanol from synthesis gas fermentation by Clostridium ragsdalei. World J. Microbiol. Biotechnol. 2012, 28, 1553-1561.

(C) 2013 by the authors; licensee MDPI, Basel, Switzerland. This article is an open access article distributed under the terms and conditions of the Creative Commons Attribution license (http://creativecommons.org/licenses/by/3.0/). 